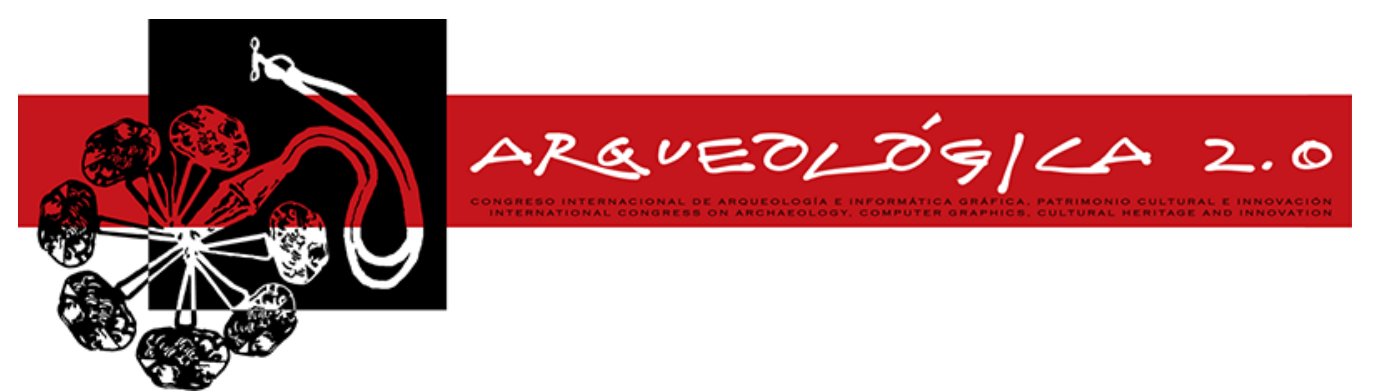

Proceedings of the $8^{\text {th }}$ International Congress

on Archaeology,

Computer Graphics,

Cultural Heritage and Innovation

'ARQUEOLÓGICA 2.0'

in Valencia (Spain),

Sept. 5-7, 2016

DOI: http://dx.doi.org/10.4995/arqueologica8.2016.3560

Received: $07 / 03 / 2016$

Accepted: $11 / 04 / 2016$

\title{
DIGITAL IMAGE ANALYSIS OF THE VISIBLE REGION THROUGH SIMULATION OF ROCK ART PAINTINGS
}

\section{ÁNALISIS DE IMAGEN DIGITAL DE LA REGIÓN VISIBLE MEDIANTE SIMULACIÓN DE PINTURAS DE ARTE RUPESTRE}

\author{
Berta Carrión-Ruiz*, Silvia Blanco-Pons, José Luis Lerma
}

Photogrammetry \& Laser Scanning Research Group (GIFLE), Department of Cartographic Engineering, Geodesy and Photogrammetry, Universitat Politècnica de València, 46022 Valencia, Spain. bercarru@doctor.upv.es; silblapo@doctor.upv.es; illerma@cgf.upv.es

\begin{abstract}
:
Non-destructive rock art recording techniques are getting special attention in the last years, opening new research lines in order to improve the level of documentation and understanding of our rich legacy. This paper applies the principal component analysis (PCA) technique in images that include wavelengths between 400-700 nm (visible range). Our approach is focused on determining the difference provided by the image processing of the visible region through four spectral images versus an image that encompasses the entire visible spectrum. The images were taken by means of optical filters that take specific wavelengths and exclude parts of the spectrum. Simulation of rock art is prepared in laboratory. For this purpose, three different pigments were made simulating the material composition of rock art paintings. The advantages of studying the visible spectrum in separate images are analysed. In addition, PCA is applied to each of the images to reduce redundant data. Finally, PCA is applied to the image that contains the entire visible spectrum and is compared with previous results. Through the results of the four visible spectral images one can begin to draw conclusions about constituent painting materials without using decorrelation techniques.
\end{abstract}

Key words: digital archaeology, cultural heritage, documentation, rock art, decorrelation techniques, digital analysis.

\section{Resumen:}

Las técnicas documentación no destructivas de arte rupestre están recibiendo especial atención en los últimos años, abriendo nuevas líneas de investigación para la mejora del nivel de documentación y comprensión de nuestro patrimonio. Este artículo aplica la técnica de análisis de componentes principales (ACP) en imágenes de longitudes de onda entre 400-700 nm (rango visible). Nuestro enfoque se centra en determinar las diferencias proporcionadas por el procesamiento de imágenes de la región del visible a través de cuatro imágenes espectrales y una imagen que abarca el espectro visible completo. Las imágenes se tomaron con filtros ópticos que recogen longitudes de onda determinadas y excluyen parte del espectro.Se preparó una simulación de pigmentos de arte ruprestre en laboratorio. Para ello se hicieron tres tipos de pigmentos diferentes simulando la composición del material de las pinturas rupestres. Se analizaron las ventajas de estudiar el espectro visible en imágenes separadas. Además, se aplicó ACP a cada una de las imágenes para reducir la información redundante. Finalmente, se realizó ACP a la imagen que abarca todo el espectro visible y se comparó con los resultados anteriores. A través de los resultados de las cuatro imágenes espectrales del visible se pueden sacar conclusiones sobre los materiales que constituyen la pintura sin aplicar técnicas de decorrelación.

Palabras clave: arqueología digital, patrimonio cultural, documentación, arte rupestre, técnicas de decorrelación, análisis digital

\section{Introduction}

Rock art is constantly exposed to natural weathering, threatening and degrading the art. There are many natural and human agents that affect the integrity of cultural sites. Independently of the level of the attacks, the different agents are steadily altering the main features conditions of the archaeological sites. Levantine rock art is located in areas exposed to direct light. Therefore, rock art recording is necessary for the longterm preservation of the fragile archaeological heritage.

"Corresponding Author: Berta Carrión-Ruiz, bercarru@doctor.upv.es 
Combining controlled photographic techniques and digital image processing techniques allow users to get ordered matrices of quantitative data, that collect the variability of certain physical properties (e.g. digital number, distribution and variability of pigments), and this variability is accessible to quantitative analysis methods (Alcalde et al. 1998).

Nowadays the analysis of rock art with digital images is considered an indirect technique essential (Brady and Gunn 2012; Cerrillo-Cuenca and Sepúlveda 2015; Clogg et al. 2000; Mark and Billo 2006). Current digital cameras are easy to use and offer high quality imagery. These devices are able to acquire the objects' reflected radiation in three visible spectral bands (Red $(R)$, Green $(\mathrm{G})$ and Blue (B)) highly correlated.

On the other hand, current digital image processing techniques are based on remote sensing techniques. (Alcalde et al. 1998) reports controlled transposition of concepts, methods and techniques from the field of remote sensing to the rock art context. These techniques are non-invasive, and they can be used to enhance paintings that cannot be easily distinguished (Mark and Billo 2006; Rogerio-Candelera 2015). This is one of the central research lines today. These concepts provide the scientific exploitation and promote the dissemination of rock art knowledge.

One of the most popular techniques used in the remote sensing field is principal components analysis (PCA). PCA is a very useful technique to achieve the decorrelation of digital image levels. Due to a high correlation between visible bands, decorrelations algorithms are used to reduce the redundant data. Thus differences between spectral bands are highlighted.

Many references can be found in which digital image processing was undertaking with these decorrelation techniques. (Rogerio-Candelera et al. 2011) examined through a laboratory test the meaning of each of the principal components obtained in PCA. (Mark and Billo 2002) applied the decorrelation strech (DS) technique to enhance rock art paintings. Furthermore, (Le Quellec et al. 2015) reported the advantage of recording deteriorated figures that would have been missed.

Using decorrelation image techniques can automate part of the image analysis. Therefore motif identification is improved and the process is accelerated in most cases (Díaz-Andreu et al. 2006; Domingo et al. 2015; Gunn et al. 2010; Rogerio-Candelera et al. 2011).

This paper applies the PCA technique in images that include wavelengths between $400-700 \mathrm{~nm}$ (visible range). Our approach is focussed on determining the difference provided by the image processing of the visible region through four images that divide the visible spectrum with a multiband image versus an image that encompasses the entire visible spectrum. The advantages of studying the visible spectrum in separate images are analysed. In addition, PCA is applied to the multiband image. Finally, PCA is performed to the image that contains the entire visible spectrum and is compared with the previous results.

\section{Nature of light}

Humans perceive objects' colour by the reflection of light. That light travels in the form of electromagnetic waves (EM) and the wavelength $(\lambda)$ is the most important characteristic of EM radiation.

Humans and visible imaging sensors such as digital cameras only can capture a portion of visible EM radiation. This range contains wavelengths between 380 $\mathrm{nm}$ and $750 \mathrm{~nm}$ (Fig. 1).

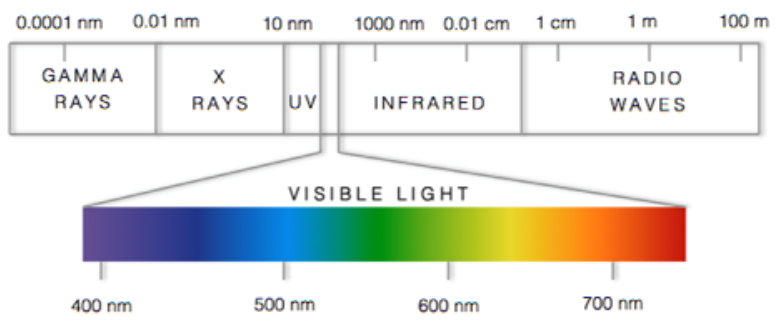

Figure 1: The Electromagnetic spectrum.

The imaging sensors receive the reflected radiation off from a scene. Nevertheless, these devices usually incorporate filters that divide the incoming EM radiation in three visible spectral bands (RGB). As (Verhoeven 2008) describes, digital cameras use a Bayer pattern with photodiodes in groups of four. In each group there are two green filters (summing up $50 \%$ of the incoming light), one red filter (summing up $25 \%$ of the incoming light) and one blue filter (summing up $25 \%$ of the incoming light).

As (Domingo et al., 2015) reported, the RGB bands are most of the times highly correlated, yielding little differences between spectral bands. This aligns with the application of decorrelations algorithms.

\section{Principal component analysis (pca)}

PCA is a multivariate analysis technique that allows the reassignation of digital number (DN) values in a new non-correlated reference system without losing information. As Cerrillo-Cuenca and Sepúlveda (2015) noted, PCA is efficient in the treatment of multiband images (RGB colour images and multispectral images).

The result of this technique is a group of non-correlated images that are the principal components. The number of principal components depends on the number of input image bands. In these components the original image information is divided.

(Rogerio-Candelera et al. 2011) reported that the second component (PC2) and the third component (PC3) can be useful to create a new colour image. Occasionally, the last component PC3 only has residual information and in some cases it allows users to detect invisible features (Cerrillo-Cuenca and Sepúlveda 2015; RogerioCandelera et al. 2011).

\section{Laboratory simulation and test}

For the simulation of rock art in laboratory we made three different pigments and simulated rock art paintings in laboratory. Manganese and charcoal were used to reproduce mineral and organic black pigments, respectively, and iron oxide was used to emulate either red or reddish colours. Some photographs were taken afterwards the pigments were painted on a stone. 
Our approach is based on the possibility to analyse motifs in rock art by means of visible images. For the testing, we analyse four images that divide the visible spectrum, each of the images contains a portion (wavelength range) of the visible region. It allows us to treat each visible spectral wavelength range separately. On the other hand we analyse the image that covers the entire visible range.

\subsection{Pigments simulation}

For the simulation of rock art paintings in laboratory, the sketches were painted based on the procedures developed by several authors (López-Montalvo et al. 2014; Vicent et al. 1996). In that way three different pigments were made:

- To reproduce mineral black pigments found in black features in Levantine rock art, manganese was used.

- To emulate organic black pigments, we used charcoal of burned pine branches.

- To emulate red or reddish colours we used iron oxide, one of the most used materials for elaborating red figures.

The technique consists in a mix of the pigment with water and animal fat. These mixes are applied on sandstone of approximately $4 \times 4 \times 0.5 \mathrm{~cm}$ and over it simple motifs were painted with a feather (Fig. 2).

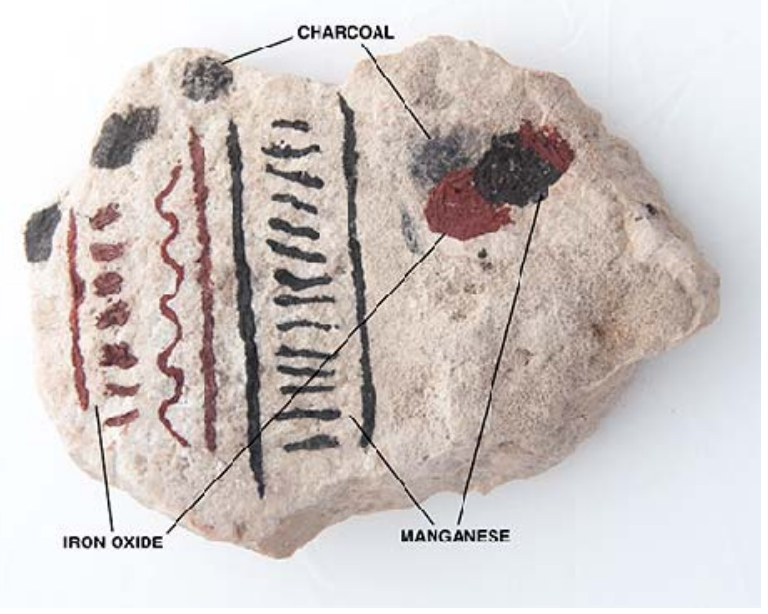

Figure 2: Simulation of rock art paintings.

\subsection{Recording}

All of the images were taken with a Fujifilm Finepix IS Pro camera with a camera lens of $60 \mathrm{~mm}$ focal length, $\mathrm{f} / 8$, ISO 100 and variable exposure time depending on the wavelength. Optical filters were required to take specific wavelengths and exclude parts of the spectrum. The filters selected were bandpass filters spanning the visible electromagnetic spectrum. These types of filters reflect unwanted wavelengths. Trying to recreate the illumination conditions of the rock art locations, the paintings were photographed with sunlight

We used five different filters of Midwest Optical Systems Inc (Midopt, 2016), Fig. 3:
- BP-550 (Near-IR/UV Block-Visible Bandpass Filter): Passes all visible light (useful range 410-690 nm).

- BP-470 (Blue Band pass Filter): This filter has a spectral bandwidth in the blue range (useful range 425-495 nm).

- BP-525 (Light Green Bandpass Filter): This filter passes the green range (useful range 500-555 nm).

- BP590 (Orange Bandpass Filter): This filter has a spectral bandwidth in the orange range (useful range 560-600 $\mathrm{nm}$ ).

- BP635 (Light Red Bandpass Filter): This filter has a spectral bandwidth in the red range (useful range 615-645 $\mathrm{nm}$ ).

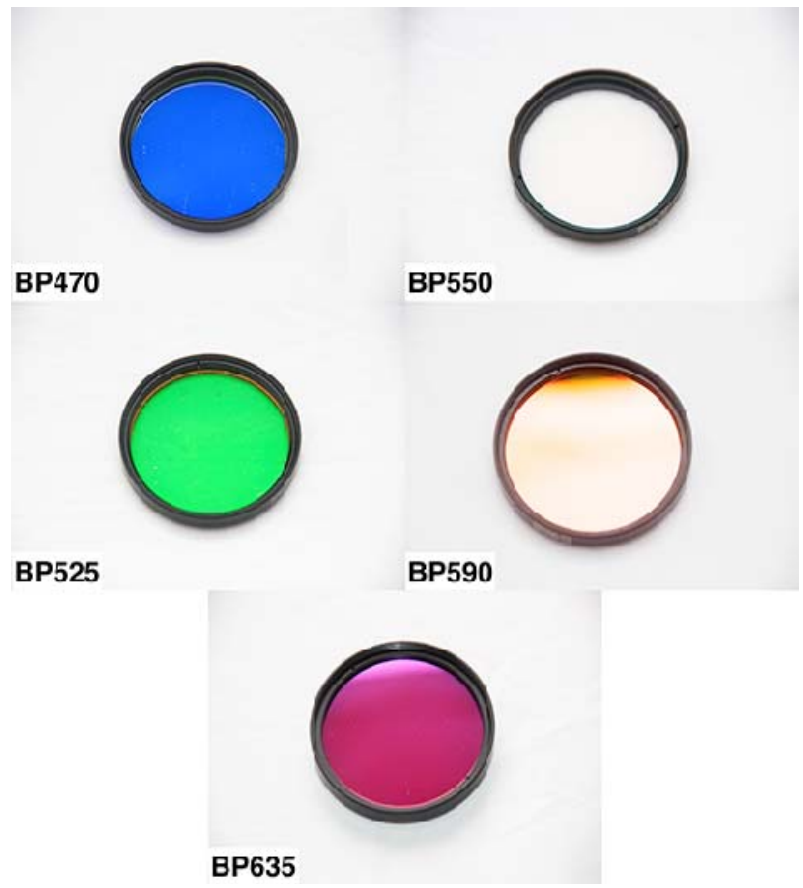

Figure 3: Five bandpass filters used for the testing. The number of MidOpt filter is pointed out in each image.

Conventional digital cameras convert the reflected radiation off from the objects in three bands: Red $(R)$, Green (G) and Blue (B). The results after interchanging the filters were five images of three-bands each one (Fig. 4), stored in RAW format, which creates files with higher colour depth and allow users to correct the exposure (Verhoeven and Schmitt 2010).

\subsection{Digital image analysis}

Images taken are analysed individually first and then jointly: 1) BP470, (blue image); 2) BP525 (green image); 3) BP590 (orange image); 4) BP635 (red image); and 5) BP550 (entire visible spectrum image).

Figure 5 shows the workflow of the digital image analysis.

\subsubsection{Greyscale Visualization}

According to (Brady and Gunn, 2012) monochrome images are easiest to deal with as only one colour needs 
to be adjusted. Therefore, each band is converted to greyscale getting monochrome images. In these images the division of pigments can be seen much more clearly (Fig. 6).

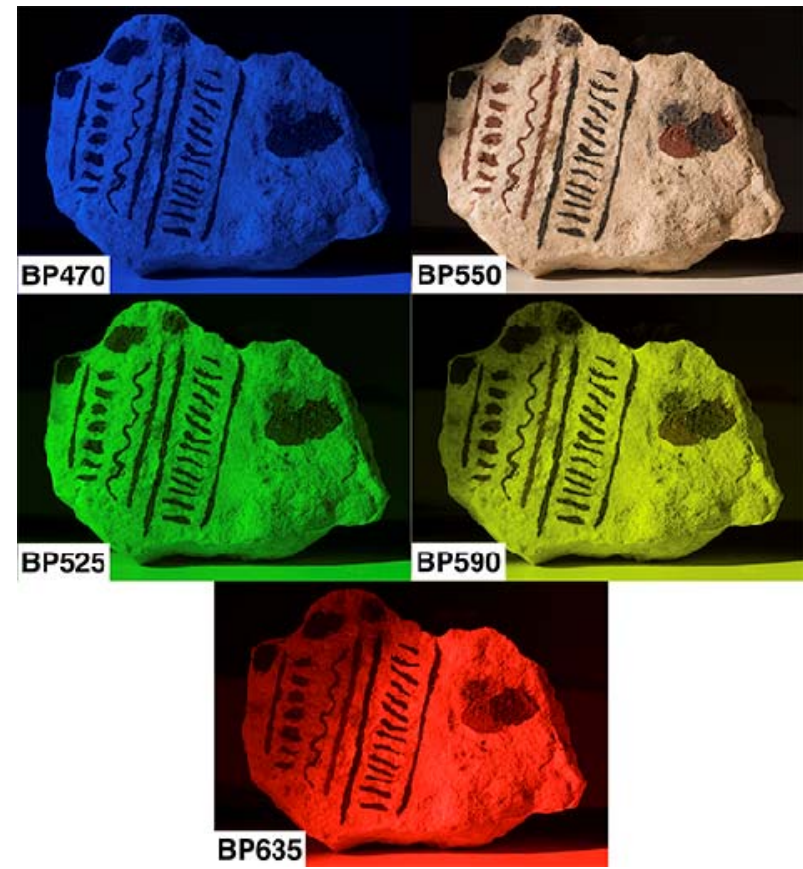

Figure 4: Output images after blocking the light with the five bandpass filters. The number of the filter used is pointed out in each image.

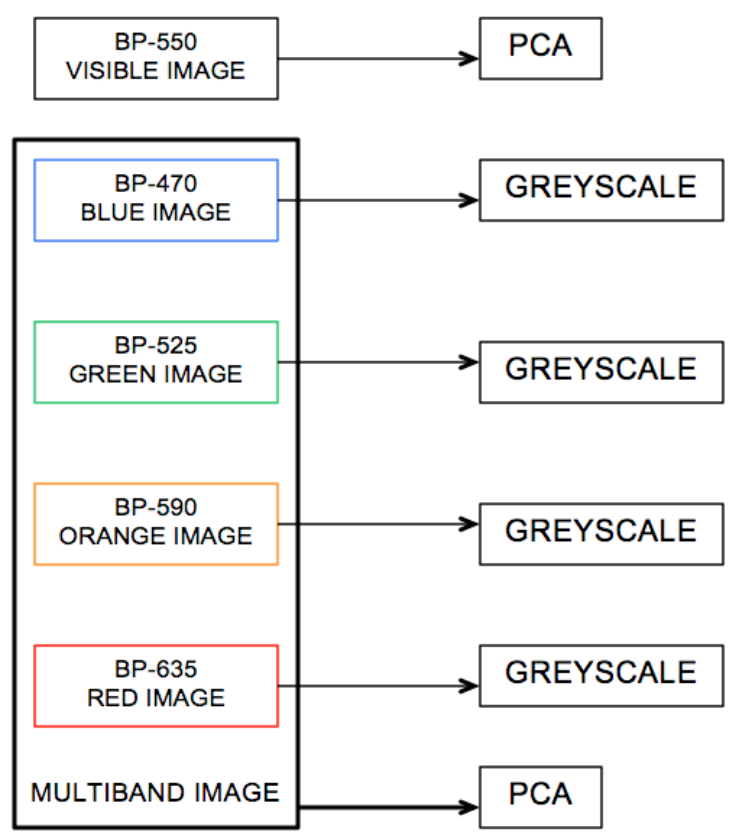

Figure 5: Digital image analysis workflow.

The three types of pigments are observed in the greyscale images. In the orange image the differentiation between iron oxide and manganese pigment is seen. Furthermore, the iron oxide pigment and the charcoal pigment with the same colour are seen (Fig. 6c). That is, there are differences between red and black pigments, but there are not differences between black pigments. In both the blue and the green images there are not differences between pigments (Figs. $6 a$ and $6 b$ ). Finally the red image shows a differentiation of the three pigments (Fig. 6d). Hence, in this case differences between these simulated pigments are seen as recorded wavelength increases.

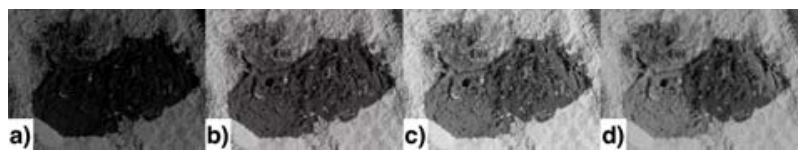

Figure 6: Detail of paintings in greyscale after bandass filter photography: a) blue, b) green, c) orange, d) red.

\subsubsection{Multiband image PCA}

To reduce redundant data, $\mathrm{PCA}$ is applied to a multiband image composed by blue, green, orange and red images. For this multiband image, four components are obtained.

Analysing the components obtained, it is observed that the lighting conditions are an important factor. Lighting should be as homogeneous as possible, avoiding areas of sun-shade. In this case the light is not homogeneous and this affects the principal component analysis.

We are going to analyse the second, third and fourth principal component (PC) due to fact that reflect hardly visible information.

The first component PC1 shows all the paintings in detail although without differentiation between pigments (Fig. $6)$.

In the PC2 the iron oxide pigment is enhanced in black; black manganese pigments are enhanced in light grey and charcoal is almost imperceptible (Fig. 7).

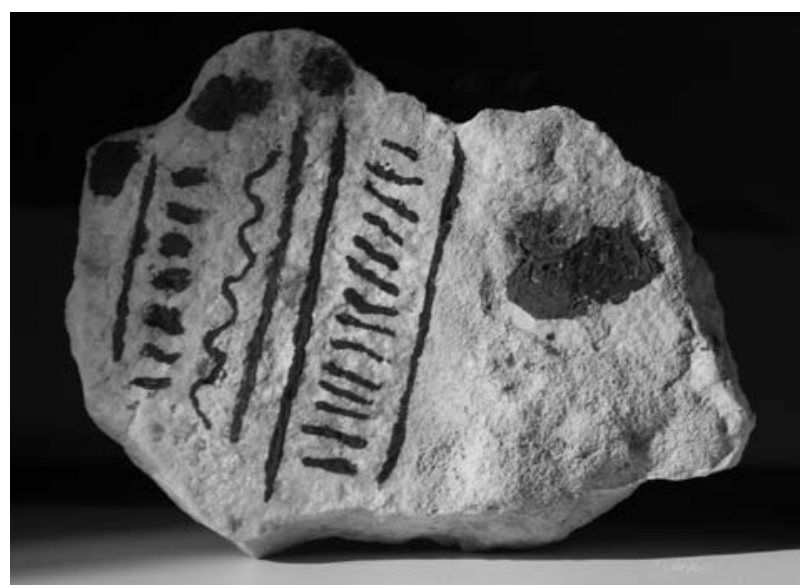

Figure 6: Principal component 1 (PC1) from the multiband image.

The third component PC3 (Fig. 8) reveals a differentiation between red pigment and black pigments. However if PC2, and PC3 are compared it is observed that the information provided is similar.

Finally in PC4 all pigments are displayed in the same colour, charcoal pigment is included (Fig. 9) although this component contains much noise and makes difficult the visualization.

\subsubsection{BP-550 PCA}

In this image, three components are obtained. After the analysis of principal components, PC2 shows that the 
paintings are divided in two tonalities, pigment composed by iron oxide is displayed in light grey/white colour and pigments composed by charcoal and manganese are visualised in dark grey (Fig. 10). Therefore manganese and charcoal pigments are not divided. In PC3 charcoal disappears remaining manganese very attenuated and iron oxide in black (Fig. 11).

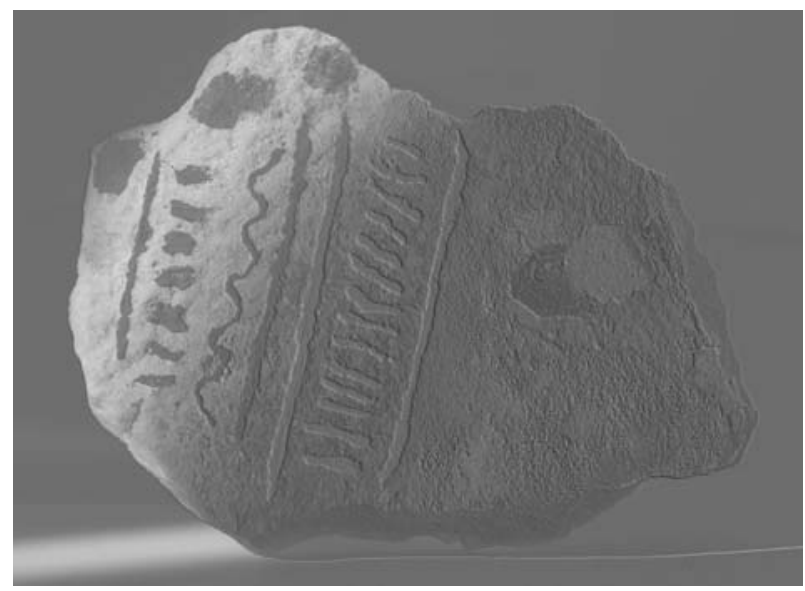

Figure 7: PC2 from the multiband image.

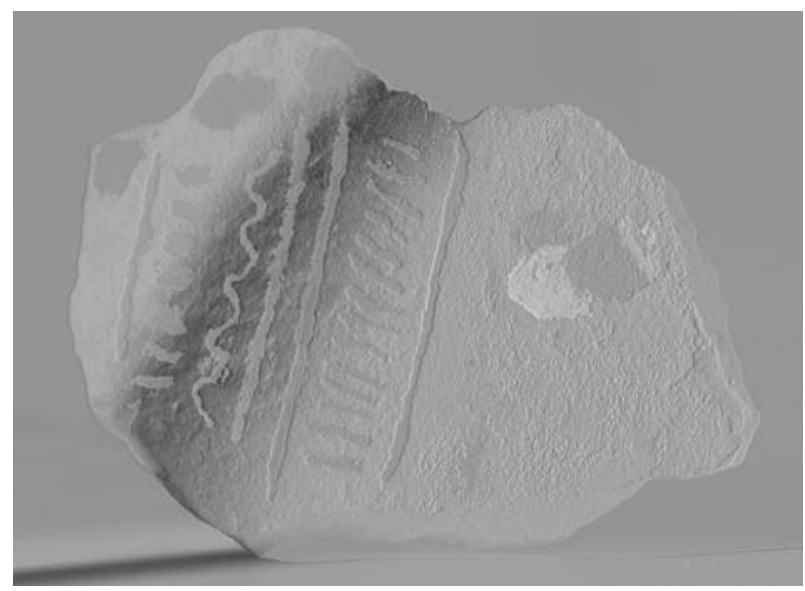

Figure 8: $\mathrm{PC} 3$ from the multiband image.

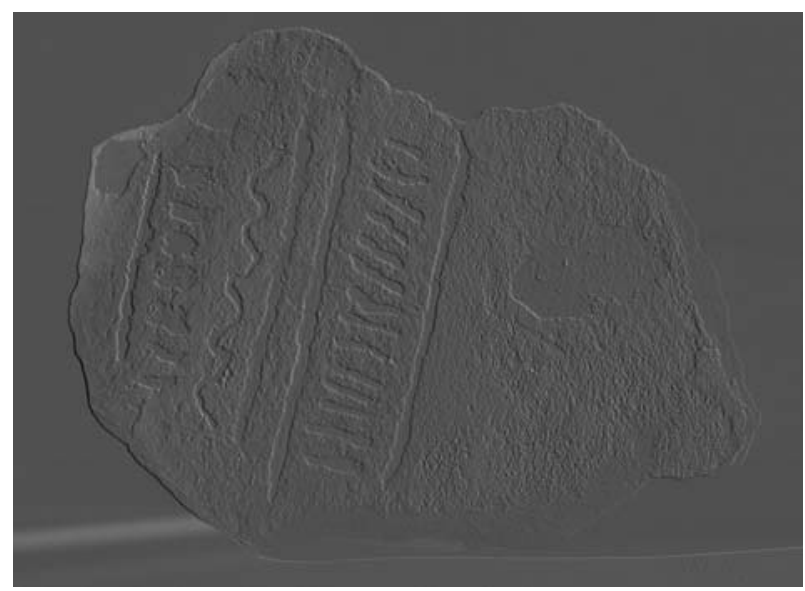

Figure 9: PC4 from the multiband image.

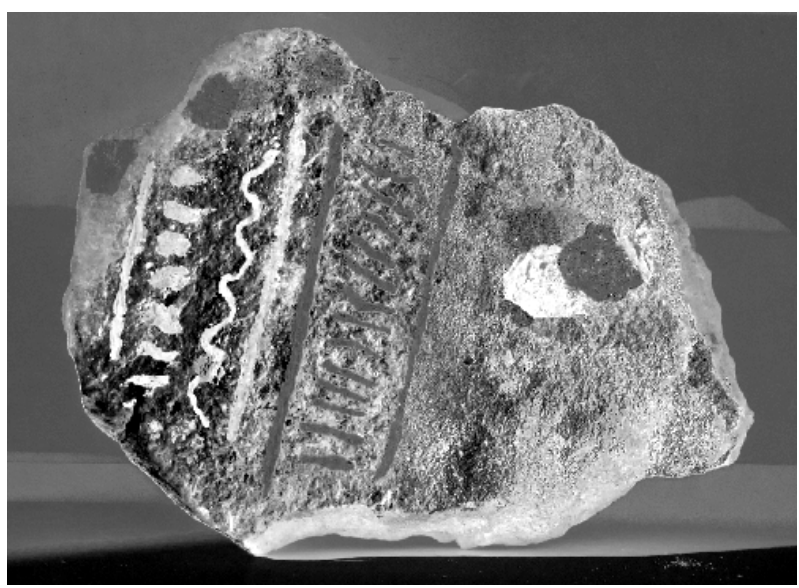

Figure 10: $\mathrm{PC} 2$ of the $\mathrm{BP}-550$ image.

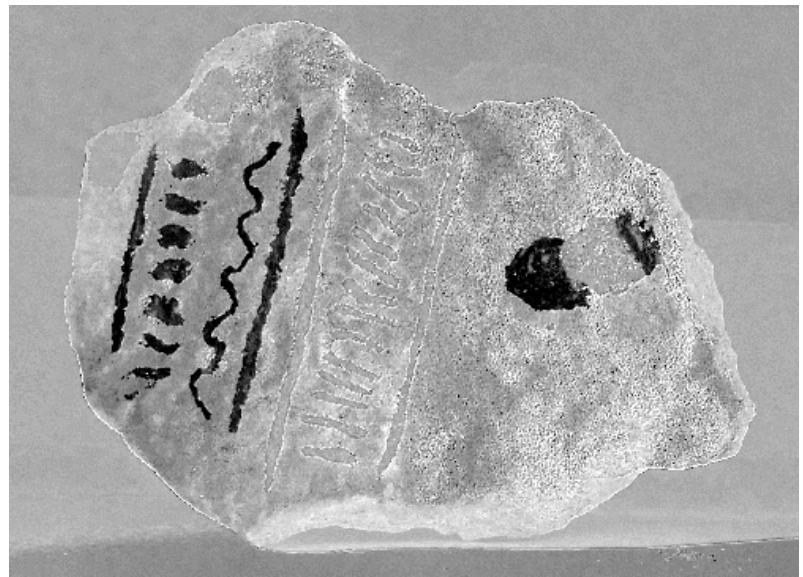

Figure 11: $\mathrm{PC} 3$ of the $\mathrm{BP}-550$ image.

\subsection{Discussion of results}

In BP-550 image, PC2 shows an iron oxide well separated from the rest of the pigments. Besides, the distinction between the pigments and the stone basis is clear. PC3 shows that the charcoal disappears, remaining manganese, what means that these two pigments are also differentiated so that they are different pigments. Hence photographing visible spectrum without splitting into bands is useful, especially when the aim is to separate either the pigment from the stone basis or separate different types of pigment. Nevertheless, it is necessary an image processing with decorrelation techniques to obtain good results.

On the other hand, with images of partial parts of the visible spectrum, one can begin to draw conclusions without applying decorrelation techniques as long as the theory that supports these images is known. The analysis of greyscale images shows that in the blue image, there are not differences between any pigments, pigments reflect the same amount of light therefore the pigments can not be differentiated. This indicates that the pigments in the blue image have a different behaviour than the rest of the images. It is necessary to ask whether this behaviour is due to its chemical composition. So, if we know the spectral behaviour of the pigments, an image that partly differentiates the visible spectrum can be very useful. 
The red image shows a differentiation of the three pigments. In order to differentiate the pigments used, the red filter is essential. Thus, the differences between these three pigments are seen as far as the recorded wavelength increases.

Therefore, in this case the division of the visible range helps users to understand the behaviour of the absorption/reflection of light in the constituent pigment materials as increases/decreases the wavelength.

Analysing the PCs of the multiband image, we can observe that charcoal disappears or attenuates in some of the principal components. PCA interprets it as a different data type. It is necessary to ask whether this is due to its chemical composition or to the pigment density on the stone. It is no possible at the moment to give the right answer. The information about the spectral response of the pigments in the visible spectrum is needed to dismiss any of the proposed options.

By comparing the results of the analysis between the greyscale images and the PCs of the multiband image, it is observed that PCA complements the analysis of the greyscale images, as it allows a higher enhancement of the pigments. Even it helps to separate painted pigments from the stone basis.

In this case both PCA (BP550 and multiband image) show detailed information about the different pigments.

\section{Conclusion}

As we have presented in this paper, digital image processing gives users the opportunity to record and analyse simulated/experimental rock art paintings in detail. The test discussed highlights the value of relatively inexpensive digital technology in recording rock art. The utilization of digital images in short wavelength ranges and the interpretation of these images related with the reflectance of the materials, allows users to establish new methodologies that might help to discover parameters such as the chemical composition of the materials.

The use of many multispectral bands (eventually hyperspectral images) can be very useful to discriminate constituent materials. The more spectral bands we consider, the more information about the pigments behaviour to light will be drawn. Nowadays, there exist a wide variety of filters available, even outside the visible region for the ultraviolet and the near infrared regions. These regions offer valuable information in the field of rock art documentation.

After the simulation and experimental analysis, more research will be devoted to contrast whether or not the results presented herein can be extrapolated to real Levantine rock art motifs composed by similar pigments and stones. Future research is devoted to analyse the behaviour of the pigments less concentrated on overlaying areas under controled lighting conditions.

\section{Acknowledgements}

The authors gratefully acknowledge the support from the Spanish Ministerio de Economía y Competitividad to the project HAR2014-59873-R.

\section{References}

ALCALDE, A.L.R., MANUEL, J., GARCÍA, V., and BERROCAL, M. C., 1998. Técnicas digitales para la elaboración de calcos de arte rupestre. Trabajos de Prehistoria, 55(1), pp. 155-169.

BRADY, L.M., \& GUNN, R.G., 2012. Digital Enhancement of Deteriorated and Superimposed Pigment Art. In Rock Art in the Digital Age, pp. 627-643.

CERRILLO-CUENCA, E., and SEPÚLVEDA, M., 2015. An assessment of methods for the digital enhancement of rock paintings: The rock art from the precordillera of Arica (Chile) as a case study. Journal of Archaeological Science, 55, pp. 197-208. DOI: 10.1016/j.jas.2015.01.006

CLOGG, P., DÍAZ-ANDREU, M., and LARKMAN, B., 2000. Digital Image Processing and the Recording of Rock Art. Journal of Archaeological Science, 27(9), pp. 837-843. DOI: 10.1006/jasc.1999.0522

DÍAZ-ANDREU, M., BROOKE, C., RAINSBURY, M., and ROSSER, N., 2006. The spiral that vanished: the application of non-contact recording techniques to an elusive rock art motif at Castlerigg stone circle in Cumbria. Journal of Archaeological Science, 33(11), pp. 1580-1587. DOI: 10.1016/j.jas.2006.02.010

DOMINGO, I., CARRIÓN, B., BLANCO, S., and LERMA, J.L., 2015. Evaluating conventional and advanced visible image enhancement solutions to produce digital tracings at el Carche rock art shelter. Digital Imaging Techniques for the Study of Prehistoric Rock Art, 2(2-3), pp. 79-88. DOI: 10.1016/j.daach.2015.01.001

GUNN, R.G., OGLEBY, C.L., LEE, D., and WHEAR, R.L., 2010. A method to visually rationalise superimposed pigment motifs. Rock Art Research, 27(2), pp. 131-136.

LE QUELLEC, J.L., DUQUESNOY, F., and DEFRASNE, C., 2015. Digital image enhancement with DStretch: Is complexity always necessary for efficiency? Digital Applications in Archaeology and Cultural Heritage, 2(2-3), pp. 5567. DOI: 10.1016/j.daach.2015.01.003

LÓPEZ-MONTALVO, E., VILLAVERDE, V., ROLDÁN, C., MURCIA, S., and BADAL, E., 2014. An approximation to the study of black pigments in Cova Remigia (Castellón, Spain). Technical and cultural assessments of the use of carbon-based black pigments in Spanish Levantine Rock Art. Journal of Archaeological Science, 52, pp. 535-545. DOI: 10.1016/j.jas.2014.09.017

MARK, R., and BILLO, E., 2002. Application of Digital Image Enhancement in Rock Art Recording. American Indian Rock Art, 28, pp. 121-128. 
MARK, R., and BILLO, E., 2006. also an increased awareness of the that several sites have been inscribed in the Robert Mark and Evelyn Billo. Mosaic A Journal For The Interdisciplinary Study Of Literature, (11), pp. 10-14.

MIDOPT., 2016. Bandpass Filters | MidOpt, Available: http://midopt.com/filters/bandpass/ [02/29, 2016]

ROGERIO-CANDELERA, M.A., 2015. Digital image analysis based study, recording, and protection of painted rock art. Some Iberian experiences. Digital Applications in Archaeology and Cultural Heritage, 2(2-3), pp. 68-78. DOI: 10.1016/j.daach.2014.11.001

ROGERIO-CANDELERA, M.A., JURADO, V., LAIZ, L., and SAIZ-JIMENEZ, C., 2011. Laboratory and in situ assays of digital image analysis based protocols for biodeteriorated rock and mural paintings recording. Journal of Archaeological Science, 38(10), pp. 2571-2578. DOI: 10.1016/j.jas.2011.04.020

VERHOEVEN, G., 2008. Imaging the invisible using modified digital still cameras for straightforward and low-cost archaeological near-infrared photography. Journal of Archaeological Science, 35(12), pp. 3087-3100. DOI: 10.1016/j.jas.2008.06.012

VERHOEVEN, G.J., and SCHMITT, K.D., 2010. An attempt to push back frontiers - digital near-ultraviolet aerial archaeology. Journal of Archaeological Science, 37(4), pp. 833-845. DOI: 10.1016/j.jas.2009.11.013

VICENT, J.M., MONTERO, I., RODRÍGUEZ, Á.L., MARTíNEZ, MAI., and CHAPA, T., 1996. Aplicación de la imagen multiespectral al estudio y conservación del arte rupestre postpaleolítico. Trabajos de Prehistoria, 53(2), pp. 19-35. 